\title{
The Activity of Jatropha curcas Cream on Day 5 of Skin Wound Healing in Mice Infected with Staphylococcus aureus
}

\author{
M. Nur Salim ${ }^{1, *}$ Dian Masyitha $^{2}$ \\ ${ }^{1}$ Laboratory of Pathology, Faculty of Veterinary Medicine, Universitas Syiah Kuala, Banda Aceh, Indonesia \\ ${ }^{2}$ Laboratory Histology, Faculty of Veterinary Medicine, Universitas Syiah Kuala, Banda Aceh Indonesia \\ *Corresponding author. Email: mnursalim@unsyiah.ac.id
}

\begin{abstract}
This research aimed to determine Jatropha sap cream's activity on day 5 of the healing process of skin wounds of mice infected with Staphylococcus aureus. Twenty-seven male mice (Mus musculus) aged 2 months and weighed 30$40 \mathrm{~g}$ were used. All mice underwent a $20 \mathrm{~mm}$ incision in the dorsal area (back) and infected with $0.2 \mathrm{ml}$ suspension of S. aureus ATCC 25923 PK/5. Treatment of open wounds was carried out twice per day. Group P1 (negative control) was smeared with cream base; group P2 (positive control) smeared with $0.1 \%$ sulfadiazine cream; and group P3 was smeared with $10 \%$ Jatropha sap cream. Macroscopic observations were carried out for 21 days, while histopathology were observed on $5^{\text {th }}$ day of healing which performed with hematoxylin-eosin (HE) staining. On day 5, pathological anatomy showed hyperaemic (redness) of the skin wounds, swelling (oedema) of the wound edges and wetness due to exudate. Based on the length of the wound on day 5, it was clear that the effect of $10 \%$ Jatropha cream and sulfadiazine cream was better than the base cream. Based on HE staining, P1, P2 and P3 had a very significant effect on the number of inflammatory and neovascularization cell infiltration in the inflammatory phase $(\mathrm{p}<0.01)$. The mean of inflammatory cells in P3 was significantly different from P2 and P1 $(\mathrm{p}<0.01)$. It can be concluded that $10 \%$ Jatropha cream can be used as a topical medicine for infected wounds of mice's skin.
\end{abstract}

Keywords: inflammation, jatropha sap cream, Staphylococcus aureus, wound healing

\section{INTRODUCTION}

Infection is an important factor affecting wound healing. Infection is caused by various pathogenic microorganisms such as bacteria [1]. Staphylococcus aureus is a gram-positive extracellular bacterium that are responsible for skin infections, cellulitis, folliculitis, subcutaneous abscesses, ulcer infections and wounds [2]. Staphylococcus aureus is a major cause associated with infection with a wide range of clinical manifestations from minor skin surface, soft tissue infections to deep wounds and organs [3].

In wound care, antibiotics are usually used to prevent infection. The widespread and irrational use of antibiotics results in bacterial resistance [4]. One of the efforts to overcome infection and bacterial resistance in wounds is to find alternative antibacterial compounds. Jatropha sap contains antimicrobial chemical compounds, namely flavonoids, saponins, tannins, and polyphenols which play a role in killing Escherichia coli, S. aureus, E. faecalis, and S. flexineri [5].
Jatropha leaves and twigs have antioxidant activity [6], immunomodulators [7], and as a wound healing [8].

The flavonoid compound of Jatropha sap could be used as antifungal, antiseptic, anti-inflammatory and cell regeneration or repairing processes. Saponins can stimulate collagen growth in wound healing, relieve pain, and stimulate new cells' formation [9]. Flavonoid compounds play a role in the inflammatory phase of wound healing by increasing interleukin-2 (IL-2) activity and lymphocyte proliferation [10]. Lymphocyte proliferation will affect the cluster of differentiation 4 (CD4 +) cells, then cause T helper 1 (Th1) cells to be activated [11]. The Th1 cells affect Specific Macrophage Activating Factor (SMAF) and Interferongamma (IFN $\gamma$ ) which can activate macrophages [12]. The flavonoid, quercetin and routine compounds in Jatropha sap improve early-phase wound healing as shown by the regulation of vascular endothelial growth factor expression for new blood vessel growth [13]. 
In topical wound care, the activity of Jatropha sap needs to be formulated in a cream form in order to be easily applied. Creams also soothe the inflammation, relieve itching and pain [14]. Based on the explanation above, it is necessary to know the concentration and potential of Jatropha cream as a natural antibacterial that inhibits bacterial growth and how the macroscopic (anatomical pathology) and histopathological features on day $5^{\text {th }}$ of healing process of the $S$. aureus infected wound.

\section{MATERIALS AND METHODS}

\subsection{Jatropha sap Cream Preparations}

The collection of Jatropha curcas L. sap was carried out purposively. The sap was obtained from Jatropha plant from the village around Universitas Syiah Kuala (USK), Banda Aceh. Plants were identified at Laboratory of Plant Biology, Study Program of Biology, Faculty of Mathematics and Natural Sciences, USK. The sap was collected at $08.00 \mathrm{a} . \mathrm{m}$. by breaking the leaf stalk, and the sap was stored in a sterile bottle.

Jatropha latex cream was made on an oil-in-water (O/W) basis using excipients which include the oil phase (stearic acid, adeps lanae and liquid paraffin) and the water phase (aquadest, triethanolamine and nipagin). The cream was made by heating at $60-70{ }^{\circ} \mathrm{C}$ the oil and water phases, separately. The oil phase was heated on water bath while the water phase was heated on hotplate. Heating process was performed until all of components in the oil phase melted and the water phase dissolved, then the two phases were mixed by pouring the water phase into the oil phase while constantly stirring as the temperature decreased until cream was formed. The cream base was then gradually added with $10 \%$ Jatropha sap to a porcelain dish containing $100 \mathrm{~g}$ of cream and stirred until homogeneous at room temperature [15].

\subsection{Experimental Animal}

The experimental animals used were 27 male mice (Mus musculus) aged 2 months with a bodyweight of 30-40 g obtained from the Faculty of Veterinary Medicine USK. The mice were placed in a sealed cage. The cage was $30 \times 40 \times 30 \mathrm{~cm}^{3}$ which was equipped with drinking water and feed containers. The food given to mice was the standard type of T79-4 pellet produced by PT. Central Proteina Prima Medan. This pellet was also used for feeding experimental animals for research purposes. The same pellet was used in both preparation and treatment periods.

During the adaptation period, each mouse was placed in one cage, fed with pellets and water ad libitum. Before being placed in a cage, according to the treatment group, the mice were weighed for initial status of body weight before treatment. Bodyweight data was used as a baseline in grouping mice for testing.

\subsection{Wound Incision and Staphylococcus aureus Infection}

In this study, an incision was made in the dorsal area (back) of all mice according to Salim et al. [16]. The procedure for wound incision was by shaving the hair with a diameter of $3 \mathrm{~cm}$ around the area of the skin, and disinfected with $70 \%$ alcohol. In order to reduce pain, local anesthesia was used on the skin area, then a skin incision is performed with a wound length of $20 \mathrm{~mm}$ to the subcutaneous area. Then, all mice were infected with $0.2 \mathrm{ml}$ suspension of $S$. aureus ATCC 25923 PK/5 at the incision site.

\subsection{Activity Test of Jatropha Cream on Wound Healing}

In wound healing study, mice were divided into three groups withthree different periods of sample collection, and three replications.. In each group, open wounds were treated with the same intensity, twice per day at 08.00 a.m. and 06.00 p.m., with the following treatments: group P1 (negative control) was treated with cream base; group P2 (positive control) was treated with $0.1 \%$ sulfadiazine cream; and group P3 was treated with $10 \%$ Jatropha sap cream.

\subsection{Macroscopic and Histopathological Observations}

The parameters observed were the phase of inflammation, epithelialization, granulation, formation of crusts, and duration of incision healing in a matter of days marked by wound closure (length and width of the wound in $\mathrm{mm}$ ). For histopathological observations, mice in each group were sacrificed by using ether solution. Skin tissue samples at the incision wound site were collected on $5^{\text {th }}$ day with 3 skin tissue samples per period. Skin tissue was cut perpendicularly. Observation on the wound healing process, namely the inflammatory phase, was carried out by using HE staining.

\subsection{Statistical Analysis}

Data from the observation of anatomical pathology were analyzed descriptively. Histopathological data were analyzed by comparing treatment groups and the sampling period. The quantitative data obtained from the observations were analysed by ANOVA. Comparison of the effects between treatments was carried out by posthoc Duncan's multiple test. Quantitative data were analyzed by SPSS. 


\section{RESULTS AND DISCUSSION}

\subsection{Anatomical Pathology}

In the activity test of $10 \%$ Jatropha sap cream (P1) on day 5 (inflammatory phase), the skin wounds of mice showed hyperaemic (redness), swelling (oedema) of wound edges and wetness due to exudate. The length of the wound on day 5 of $10 \%$ Jatropha cream and sulfadiazine cream (positive control) was better than the base cream (negative control) (Table 1). The image of skin wounds of the mice receiving cream-based treatment, sulfadiazine cream and 10\% Jatropha latex cream on the 5 th day of healing is presented in Figure 1.

Table 1. Length of mice skin wounds infected with $S$. aureus on day 5 after topical application of cream base, sulfadiazine cream and Jatropha cream

\begin{tabular}{|l|l|}
\hline Group & Length of wounds (cm) \\
\hline Cream base (P1) & 1.20 \\
\hline $0.1 \%$ Sulfadiazine (P2) & 0.96 \\
\hline $10 \%$ Jatropha sap (P3) & 0.96 \\
\hline
\end{tabular}

The redness and oedema of the wound was the result of an inflammation process. This reaction was formed by vasoconstriction of blood vessels which was immediately followed by vasodilation. The presence of a blood clot was a reaction of activated platelets and fibrinogen protein which was released by blood vessels. Fibrinogen thenformed fibrin threads [17].

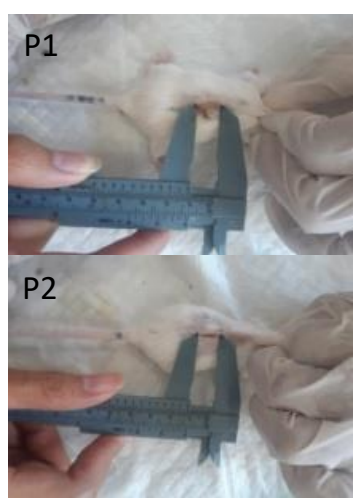

P3

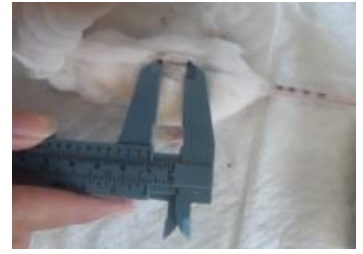

Figure 1 Overview of skin wounds infected by Staphylococcus aureus and treated with cream base (negative control, P1), Sulfadiazine cream (positive control, P2) and 10\% Jatropha cream (P3) on day 5 of wound healing process.

\subsection{Histopathology}

The incision wound on day 5 after administration of cream base (P1) and sulfadiazine $0.1 \%$ (P2) was dominated by dense inflammatory cells. The administration of $10 \%$ Jatropha sap cream (P3) at the wound site showed spreaded inflammatory cells with moderate density (Figure 2). Based on one-way
ANOVA test, the treatment with cream base(P1), $0.1 \%$ sulfadiazine (P2) and 10\% Jatropha sap cream (P3) had a significant effect $(\mathrm{p}<0.01)$ on the amount of inflammatory cell infiltration during the inflammatory phase of wound healing in mice skin. The Duncan test (Table 2) showed that the number of inflammatory cells after the administration of $10 \%$ Jatropha cream (P3) was significantly different $(\mathrm{p}<0.01)$ from the number of inflammatory cells after the administration of $0.1 \%$ sulfadiazine (P2) and cream-base (P1).

Table 2. Average number ( \pm SD) of inflammatory cells in the inflammatory phase of skin wound healing in Staphylococcus aureus infected mice

\begin{tabular}{|l|l|}
\hline Groups & $\begin{array}{l}\text { Means of inflammatory } \\
\text { cells }\end{array}$ \\
\hline Cream base (P1) & $302.00 \pm 7.20^{\mathrm{c}}$ \\
\hline $0.1 \%$ Sulfadiazine (P2) & $243.00 \pm 8.80^{\mathrm{b}}$ \\
\hline $10 \%$ Jatropha sap (P3) & $148.67 \pm 1.50^{\mathrm{a}}$ \\
\hline
\end{tabular}

a, bifferent superscripts in the same column means significant differences $(\mathrm{P}<0.01)$

From our result, it can be seen that the number of inflammatory cells after the administration of $10 \%$ Jatropha cream was effectively reducing the number of inflammatory cells. It showed that the administration of $10 \%$ Jatropha cream accelerated the inflammatory phase of the wound healing process of $S$. aureus infection on micecskin. The involvement of inflammatory cells that dominate the wound area indicateed that the inflammatory process was occuring . The inflammatory phase is a very important stage in wound healing process, if the inflammatory process lasts for a long time, the wound healing will be hampered [18].

The decrease in the number of inflammatory cells after the administration of $10 \%$ Jatropha sap cream was due to the presence of saponins and flavonoids in Jatropha sap which had anti-inflammatory potency [7, 19, 20]. The bark and roots of J. curcas contain compounds with antibacterial activity [21]. J. curcas leaf extract showed very strong antibacterial and antifungal activity and relatively moderate antioxidants [22]. Methanol and hexane extracts of $J$. curcas leaves showed antimicrobial, antiviral, antioxidant, anticancer, analgesic, anti-inflammatory, anti-bleeding and wound healing properties [23]. Methanol extract of J. curcas showed systemic anti-inflammatory activity in rats induced by acute carrageenan [24]. The ethanol extract of $J$. curcas leaves had peripheral analgesic and antibacterial activity [25]. The crude extract of J. curcas stems had the ability to inhibit the growth of bacteria and fungi, thereforeit had the potency as broad-spectrum 
antimicrobial substances and can be used in the management of microbial infections [9].

Observations of the incision on day 5 after applying cream base (P1), the wound area was haemorrhagic, hyperaemic, and neovascular was formed slightly. After the application of $0.1 \%$ sulfadiazine (P2) and $10 \%$ Jatropha cream (P3), the wound showed an increase in neovascular volume (Figure 2). Based on one-way ANOVA test, the treatment of cream base (P1), $0.1 \%$ sulfadiazine (P2), and 10\% Jatropha sap cream (P3) had significant effect $(\mathrm{p}<0.01)$ in the inflammatory phase of the wound healing on mice skin infected with $S$. aureus (Table 3).

Table 3. Mean number $( \pm$ SD) of neovascular in the inflammatory phase of skin wound healing of Staphylococcus aureus infected mice

\begin{tabular}{|l|l|}
\hline Groups & $\begin{array}{l}\text { Means of neovascular } \\
\text { number }\end{array}$ \\
\hline Cream base (P1) & $12.00 \pm 5.50^{\mathrm{a}}$ \\
\hline $0.1 \%$ Sulfadiazine (P2) & $24.00 \pm 5.00^{\mathrm{b}}$ \\
\hline $10 \%$ Jatropha sap (P3) & $26.60 \pm 7.50^{\mathrm{b}}$ \\
\hline
\end{tabular}

a, b Different superscripts in the same column means significant differences $(\mathrm{P}<0.01)$
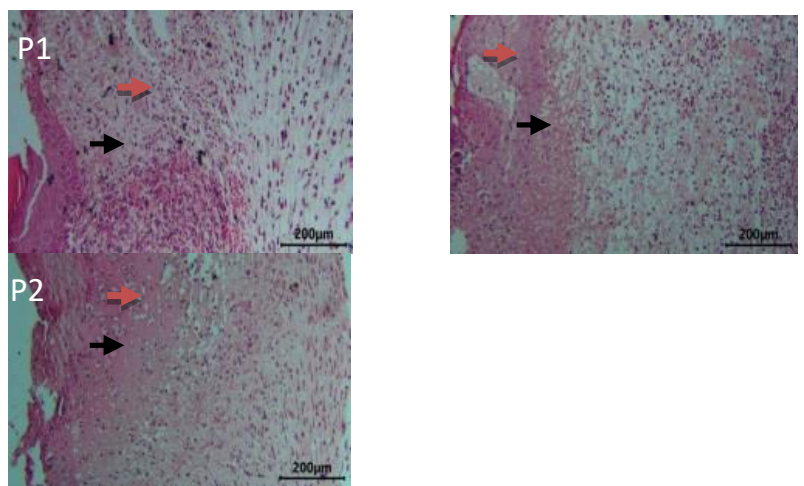

Figure 2. Staphylococcus aureus infected wounds of mice skin after treatment with cream base (negative control, P1), sulfadiazine cream (positive control, P2) and 10\% Jatropha sap cream (P3) on day 5 . Inflammatory cells (black arrows); neovascular (red arrow) (HE, 10x).

The Duncan test showed that the amount of neovascular after the administration of $10 \%$ Jatropha sap cream (P3) was significantly different $(p<0.01)$ compared to the number of neovascular after cream base administration (P1). The amount of neovascular in $10 \%$ Jatropha cream administration(P3) compared to $0.1 \%$ sulfadiazine (P2) was not significantly different $(\mathrm{p}>0.01)$. The administration of $10 \%$ Jatropha cream
(P3) increased the number of neovascularization in the wound area $[16,26]$. The formation of new blood vessels in the wound area accelerated wound healing [26]. The saponin content in Jatropha sap plays a role in stimulating the growth of new cells and angiogenesis which is a process of forming neovascularization in wounds. The increased blood supply to the tissues carries nutrients necessary for the healing process [27].

\section{CONCLUSIONS}

The research confirmed that $10 \%$ Jatropha cream can be used as a topical treatment, which had antibacterial activity, anti-inflammatory, and neovascular stimulator in mice skin wound infected with $S$. aureus. It is necessary to study the bioactive compound or phytochemical substances contained in Jatropha cream responsible for antibacterial, antiinflammatory and collagen tissue synthesis.

\section{AUTHORS' CONTRIBUTIONS}

MNS and DM designed, performed the research and prepared the manuscript.

\section{ACKNOWLEDGMENTS}

The authors gratefully acknowledge the Research and Community service institutions, Universitas Syiah Kuala for funding this research.

\section{REFERENCES}

[1] E. Jawetz, J.L. Melnick, E.A. Adelberg, Medical Microbiology, Book 1, Salemba Medika Publiher, Jakarta, 2005.

[2] S. Krishna, L.S. Miller, Host-pathogen interactions between the skin and Staphylococcus aureus, Curr. Opin. Microbiol. 15 (2012) 28-35.

[3] K.U. Jansen, D.Q. Girgenti, I.L. Scully, A.S. Anderson, Vaccine review: "Staphyloccocus aureus Vaccines: Problems and prospects". Vaccine 31 (2013) 2723-2730.

[4] R. Bisht, A. Katiyar, R. Singh, P. Mittal, Antibiotic resistance - A global issue of concern. Asian J. Pharm. Clin. Res. 2(2) (2009) 3-5.

[5] A.K. Sharma, M. Gangwar, R. Tilak, G. Nath, A.S.K. Sinha, Y.B. Tripathi, D. Kumar, Comparative in vitro antimicrobial and phytochemical evaluation of methanolic extract of root, stem and leaf of Jatropha curcas Linn. J. Pharm. 4(30) (2012) 34-40.

[6] D. Setyaningsih, C. Panji, D.D. Perwatasari, Study of antioxidant and antimicrobial activities of fractions and extracts from the leaves and twigs of 
Jatropha curcas $L$. and their utilization in personal hygiene products. Agritech, 34(2) (2014) 126-137.

[7] H.I. Abd-Alla, F.A. Moharram, A.H. Gaara, M.M. El-Safty, Phytoconstituents of Jatropha curcas L. leaves and their immunomodulatory activity on humoral and cell-mediated immune response in chicks. Zeitschrift fur Naturforschung C, 64 (2009) 495-501.

[8] K. Sachdeva, P. Garg, M. Singhal, B. Srivastava, Wound healing potential of extract of Jatropha curcas L. (stem bark) in rats. Pharm. J. 3(25) (2011) 67-72.

[9] O.O. Igbinosa, E. Igbinosa, O.A. Aiyegoro, Antimicrobial activity and phytochemical screening of stem bark extracts from Jatropha curcas (Linn). Afr. J. Pharm. Pharmacol. 3(2) (2009) 058-062.

[10] Y. Jiao, J. Wen, X. Yu, Influence of flavonoid of Astragalus membranaceus's stam and leaves on the function of cell mediated immunity in mice. Heilongjiang University, 2005. [online]: URL. http: // www.ncbi.nlm.nih.gov/pubmed.

[11] K.G. Baratawidjaja, Basic Immunology, $5^{\text {th }}$ Ed. Medical Faculty, University of Indonesia, Balai Publiher, Jakarta, 2002.

[12] W.E. Paul, Fundamental Immunology, $6^{\text {th }}$ Ed. A Wolters Kluwer Company, Philadelphia, 2003.

[13] C.O. Esimone, C.S. Nworu, C.L. Jackson, Cutaneous wound healing activity of a herbal ointment containing the leaf extract of Jatropha curcas L. (Euphorbiaceae). Int. J. Appl. Res. Nat. Prod. (2008). [Online Journal] http://www.healthysynergies.com.

[14] H.C. Ancel, Pengantar Bentuk Sediaan Farmasi. $4^{\text {th }}$ Ed. Farida Ibrahim, Penerjemah. UI Press, Jakarta, 1989 pp. $390-398$.

[15] M.C. Muntiaha, P.V.Y. Yamlean, W.A. Lolo, Uji efektivitas sediaan krim getah jarak cina (Jatropha multifida L.) untuk pengobatan luka sayat yang terinfeksi bakteri Staphylococcus aureus pada kelinci (Orytolagus cuniculus). Pharmacon Jurnal Ilmiah Farmasi, 3(3) (2014) 294-302.

[16] M.N. Salim, M. Silvia, D. Aliza, D. Masyitha, C.D. Iskandar, R. Rusli, S. Sugito, M. Hasan, M. Sabri, A. Harris, Efficacy of Jatropha curcas latex cream in the epithelialization phase of wound healing in mice skin. 1st ICVAES 2019. E3S Web of Conferences 151, 01038. (2020) 153-158.

[17] S. Scwartz, The essence of the principles of surgery, (Translate by Laniyati et al). $6^{\text {th }}$ Ed. ECG, Medical Book Publisher, Jakarta, 2000.
[18] T.O.H. Prasetyono, general concept of wound healing, revisted. J. Med. J. Indones. 18(3) (2009) 206-214.

[19] B.S. Nayak, K.N. Patel, Pharmacognostic studies of the Jatropha curcas leaves. Int. J. Pharm. Tech. Res. 2(1) (2010) 140-143.

[20] M.N. Salim, D. Masyitha, A. Harris, U. Balqis, C.D. Iskandar, M. Hambal, D. Darmawi, Antiinflammatory activity of Jatropha curcas Linn. latex in cream formulation on CD68 expression in mice skin wound, Vet. World 11(2) (2018) 99-103.

[21] A. Namuli, N. Abdullah, C.C. Sieo, S.W. Zuhainis, E. Oskoueian, J. Med. Plant. Res. 5(16) (2011) 3982-3990.

[22] L. Wei, W. Zhang, L. Yin, F. Yan, Y. Xu, F. Chen, Extraction optimization of total triterpenoids from Jatropha curcas leaves using response surface methodology and evaluations of their antimicrobial and antioxidant capacities. Electronic. J. Biotech., 18 (2015) 88-95.

[23] P. Wongkrajang, N. Nurlely, S. Phonchirasilp, R. Temsiririrkkul, S. Thongpraditchote, N. Ruangwises, A. Mitrevej, R. Khammanit, R. Hanyongyuth, Hemostatic effect of n-hexane extracts of Jatropha curcas Linn leaf. Mahidol Univ. J. Pharm. Sci. 42 (3) (2015) 110-117.

[24] A.Y. Mujumdar, A.V Misar, Anti-inflammatory activity of Jatropha curcas roots in mice and rats. J. Ethnopharm. 90 (2004) 11-15.

[25] J. Sangeetha, K. Divya, M.V. Prashanth, A. Vamshikrishna, G.L. Rani, Anti-inflammatory and antibacterial activity of Jatropha curcas Linn. J. Pharm. Res. Health Care, 2 (2009) 258-262.

[26] U. Balqis, D. Darmawi, C.D. Iskandar, M.N. Salim, Angiogenesis activity of Jatropha curcas L. latex in cream formulation on wound healing in mice. Vet. World 11(7) (2018) 939-943.

[27] I.P.S. Sabirin, A,M. Maskoen, B.S. Hernowo, Role of Noni (Morinda citrofolia L) leaf ethanolic topical application on wound healing examined from CD34 immunoexpression and colaagen on wistar rats. J. Kedokteran Bandung, 45 (4) (2013) 226-23 